\title{
(IST) Cross-Strait Relations Today: Challenges and Opportunities
}

\author{
Chunjuan Nancy Wei \\ Chair, International Political Economy \& Diplomacy \\ International College \\ University of Bridgeport, Bridgeport, CT
}

\section{Abstract}

The China-Taiwan relationship has been deeply influenced by path dependency, structural shifts in great power politics, and partisan struggles across the Taiwan Strait. One may wonder, what had suddenly changed between 2008 and 2010 to make a landmark free trade deal possible between the archrivals? Why was it signed despite domestic opposition? How did these rivals embrace each other economically when they still harbored significant political differences? Will this economically beneficial agreement to Taiwan come at a political cost? How will this deal influence East Asian regional economic integration, especially between Northeast Asia and ASEAN?

\section{Outline}

- Introduction

- The "China" tangle

- Six rounds of negotiation

- Ma's diplomatic truce

- Success of ambiguity: the Tamamushiiro approach

- Free trade or birdcage: ECFA's implications for Taiwan's Pan-Greens

- Whither cross-Strait relations?

Mencius: "The great power should treat the small with magnanimity, and the small should respond to the great with prudence. In so doing, the great power brings peace to the world and the small power protects its kingdom."

\section{Tamamushi-iro approach}

Tamamushi is the Japanese name of a jewel beetle whose color changes depending on the angle of the observer and the source of the light. The iro (colors) may be different but the insect is still the same. According to a Japanese scholar, the term tamamushi-iro bears "a positive connotation" in Japanese culture. In diplomacy, tamamushi-iro solution refers to a deal reached through a vague, ambiguous term that is designed to please both sides. With mutual appreciation, the parties involved would not challenge each other's interpretations.

The "1992 Consensus" - One China with different interpretationproved the winning formula

\begin{tabular}{|c|cc|l|}
\hline \multicolumn{4}{|c|}{ Table 1.1 Cross-Strait Agreements Since May 2008 } \\
\hline $\begin{array}{c}\text { Negotiation } \\
\text { Rounds (\# of } \\
\text { Agreements) }\end{array}$ & Date & Place & Agreement Contents \\
\hline \hline Round 1 (2) & $\begin{array}{c}\text { Jun. 8-13 } \\
2008\end{array}$ & $\begin{array}{c}\text { Beijing, } \\
\text { China }\end{array}$ & $\begin{array}{l}\text { Agreement on Cross-Strait Tourism of Mainland Residents to Taiwan } \\
\text { Minutes of Talks on Cross-Strait Chartered Flights }\end{array}$ \\
\hline Round 2 (4) & Nov. 4 2008 & $\begin{array}{c}\text { Taipei, } \\
\text { Taiwan }\end{array}$ & $\begin{array}{l}\text { Agreement on Cross-Strait Air Transport } \\
\text { Agreement on Cross-Strait Sea Transport } \\
\text { Agreement on Cross-Strait Postal Services } \\
\text { Agreement on Cross-Strait Food Security }\end{array}$ \\
\hline $\begin{array}{c}\text { Round 3 (3) } \\
\text { with 1 } \\
\text { consensus }\end{array}$ & $\begin{array}{c}\text { Apr. 26 } \\
2009\end{array}$ & $\begin{array}{c}\text { Nanjing, } \\
\text { China }\end{array}$ & $\begin{array}{l}\text { Cross Strait Financial Cooperation Agreement } \\
\text { Supplementary Agreement on Cross-Strait Air Transport } \\
\text { Agreement on Joint Cross-Strait Crime-fighting and Mutual Judicial } \\
\text { Assistance } \\
\text { Consensus on Mainland Investment in Taiwan }\end{array}$ \\
\hline Round 4 (3) & $\begin{array}{c}\text { Dec. 21-5 } \\
2009\end{array}$ & $\begin{array}{c}\text { Taichung, } \\
\text { Taiwan }\end{array}$ & $\begin{array}{l}\text { Agreement on Cooperation of Agricultural Product Quarantine and } \\
\text { Inspection } \\
\text { Agreement on Cooperation in Respect of Standards, Metrology, Inspection \& } \\
\text { Acreditation }\end{array}$ \\
\hline Round 5 (2) & $\begin{array}{c}\text { Jun. 29 } \\
2010\end{array}$ & $\begin{array}{c}\text { Chongqing, } \\
\text { China }\end{array}$ & $\begin{array}{l}\text { Agreement on Cooperation in Respect of Fishing Crew Affairs } \\
\text { Economic Cooperation Framework Agreement (ECFA) } \\
\text { Cross-Straits Agreement on Intellectual Property Right Protection \& Cooperation }\end{array}$ \\
\hline Round 6 (1) & $\begin{array}{c}\text { Dec. 20-2 } \\
2010\end{array}$ & $\begin{array}{c}\text { Taipei, } \\
\text { Taiwan }\end{array}$ & Medical and Health Cooperation Agreement \\
\hline Source: The Straits Exchange Foundation \\
\hline
\end{tabular}

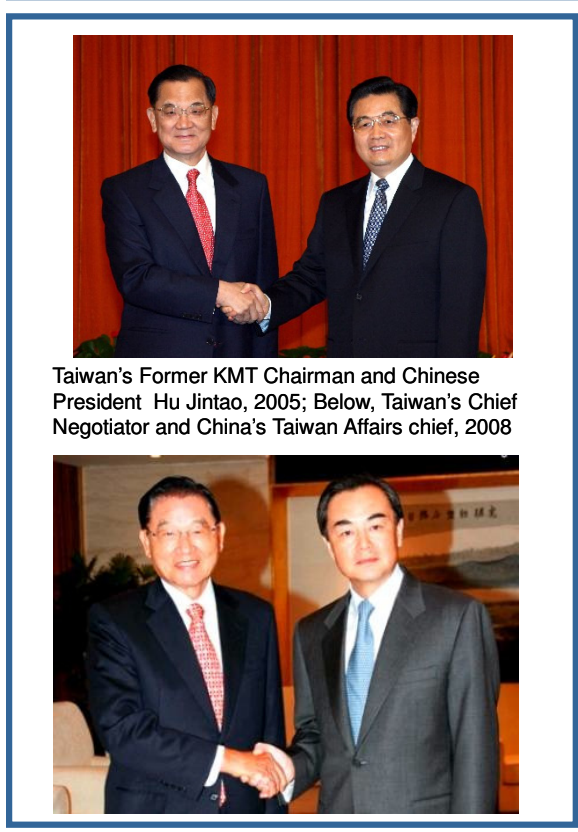

\section{Conclusion}

This research explains the opportunities and challenges in cross-Taiwan-Strait Relations. With rapid cross-Strait reconciliation and ECFA in effect, it is anticipated that regional integration between Northeast Asia and ASEAN will be accelerated. Despite positive developments, structural problems remain; the cross-Strait relationship is still fraught with many uncertainties. On the triangular relationships, Taipei will continue to request US arms sales; the arms sales are expected to be a repeated source of friction for US-China relations. In Taiwan's domestic front, identity politics remains a potent weapon in electoral seasons, which may once again split the society. On the cross-Strait level, the Pan-Greens' unwillingness to accept the "1992 Consensus" as a prerequisite for negotiations with China may derail future cooperation should the DPP return to power. Ultimately, Beijing's national interest and its degree of tolerance of the Pan-Greens' independence agenda may deter- mine whether the Taiwan Strait should once again be packed with tourists or regionally plugged with landmines. 